\title{
Securitization and the (Mis)handling of Difference: Narratives about Fear from US-Citizen Muslims
}

\author{
Shaundel Sanchez
}

\section{Abstract}

This paper demonstrates the everyday ways that US-citizen Muslims who live or have lived in the United Arab Emirates contribute to racialized securitization. While conducting ethnographic research from 2015 to 2019, I learned how the members of a close-knit collectivity, who call themselves "The Community", express different reasons for their emigration from the United States in the early 1990s. These differing motivations fell along racial lines. My white interlocutors implied that they felt unsafe in the United States because of violence and criminality largely associated with African Americans. My Black research participants, on the other hand, feared securitization measures that disproportionately surveil or target them, measures that are legitimized by my white participants' vocalized fears. Adherents associated with my interlocutors' variant of Islam, Tablighi Jama'at, gloss over internal fissures and inequalities, including different life experiences, that derive from socio-economic, racial, and national diversity in order to uphold the illusion of a cohesive Muslim community. By overlooking differences between their emigration narratives, some Community members have reinforced their role within US securitization. They propagate these security norms even when securitizing mechanisms in their host country operate along different ethnic, racial, and national hierarchies.

\section{Introduction}

In 2010, I moved to Sharjah, United Arab Emirates (UAE) from California to work for a not-for-profit organization. At the time, I would have preferred to find work in the United States (US), but I graduated from my undergraduate institution into the Great Recession. Unable to establish any sense of financial security, which was likely compounded by my choice to convert to Islam and wear a headscarf, I accepted an offer to work in the UAE. Almost a year after living in my host country, I came across a group of compatriot US-citizen Muslims who had migrated to the UAE in the early 1990 s.

I moved back to the US to attend graduate school in 2013, but I returned to the UAE two years later to begin research as an anthropologist. 
For my research, I was initially interested in why my compatriots had migrated from the US to the UAE, where they also felt insecure. However, they explicitly chose to use the word "safety." This word signaled their concern with general violence, as opposed to the type of human security that informed my reason for migrating. Through this research, I learned that even after decades of living in the UAE, they continued to hold onto the notion that the US is an unsafe space, albeit along different racial lines.

Although my interlocutors verbalized the same reason for moving from the US to the UAE, the deeper meanings and perceptions about their sense of safety differed significantly. Of course, they do not always explicitly articulate the tensions they encountered. However, from my observations about their everyday lives and theoretical knowledge about the period of their migration, I illustrate that my research participants have internalized racialized security measures foundational to the US' so-called liberal democracy. Thus, my analysis presents this group as a microcosm of the hidden fissures that develop between US citizens and US non-citizen residents because of securitization.

In this chapter, I discuss US securitization measures that primarily target Black Americans, but not most white citizens. Securitization, as theorized by the Copenhagen School (Buzan et al. 1998), occurs when governing authorities perform a speech act that frames an issue as an existential threat. The issue must elicit public support to implement exceptional measures that are unjustifiable under ordinary circumstances. The theory, as the Copenhagen School outline, centers the state. However, anthropologists who both critique and employ securitization as a framework have explored how communities, groups, and individuals configure security - that is, in ways outside of the state (Diphoorn/Grassiani 2015; Goldstein 2010). In a previous publication, I explore how my research participants consciously and unconsciously self-govern and enforce US security measures, even when living abroad (Sanchez 2019). The present chapter focuses on how such practices are reinforced through the (re)telling of their migration narratives. In writing about the ways my research participants (re)produce security measures that disproportionally target Black people in the US, I contribute to theoretical discussions about securitization as a concept and its inclusion of race, manifest or not. Race is central to my argument because of its centrality as a differentiating category throughout US history, and my research participants' racial identities inform their notions of safety in the US. Still, other differentiating categories such as socio-economic status, ethnicity, and nationality also feature within the US', the UAE's, and my interlocutors' (meta)narratives about security. 
In 2020, Howell and Richter-Montpetit published an article outlining the ways that securitization is, at base, racist and anti-Black - rooted in racist political thought - all the while promoting civilizationism. For them, securitization theory creates and perpetuates a binary between normal and exception that is associated with notions of progress from primal anarchy to normal politics. They argue that by using the theory, one promotes the notion that civilizations achieve normal politics, and securitization ensures states will not backslide into primal anarchy (Howell/Richter-Montpetit 2020, p. 7). Wæver and Buzan (2020) have responded that the theory of securitization is not prescriptive, but instead, a framework for analyzing the consequences that occur when a state has been securitized.

This chapter combines the pitfalls of securitization theory that Howell and Richter-Montpetit identify with Wrver and Buzan's defense that securitization theory allows for understanding the way the world is as opposed to the way it ought to be. In doing so, I engage the work of scholars like Moffette and Vadasaria (2016, p. 291), who assert that the concept of securitization signals how people deemed a threat are policed, criminalized, and subjected to violence. I would also add that securitization can be understood by examining how individual and broader metanarratives justify such policing, criminalization, and violence. According to Moffette and Vadasaria (2016) and Howell and Richter-Montpetit (2020), securitization theory fails to engage the underpinnings of racism, and even colonial modernity, that are foundational to liberalism. This is the case despite naive democratic peace literature that is "rooted in the liberal belief that if the people's will is freely expressed, it will be pacific" (Mann 2005, p. 22).

Securitization theory's fixation on the state, I argue, also perpetuates a homogenizing caricature of entire states or even regions. In examining how people of different races interpret securitization and are securitized, I demonstrate that it is essential to move beyond common metanarratives about certain parts of the world (cf. Koch 2016b). In particular, these metanarratives perpetuate assumptions of self-identifying liberal democracies as the ultimate achievement of normalcy, modernity, and inclusiveness, while ethnocratic or illiberal regimes are presented as the exception. Through an ethnography of the everyday, this research demonstrates that liberal "institutions also reinforce privilege (and lack thereof) in and through 'ethnocratic' mechanisms and imaginaries of people, place, and claims to belonging" (Vora/Koch 2015, p. 548). So-called liberal institutions and entire states that hide behind the moniker of "liberality" can do so because they perpetuate the guise of tolerance and white civility (Moffette/ Vadasaria 2016, p. 297). This is the case, even though scholars like Mann 
go as far as to assert that there is a link between modern democracy and murderous ethnic cleansing (Mann 2005).

In the argument that follows, however, it is individual citizens who reinforce the racial dimensions of security by ascribing their reasons for emigrating from the US to the UAE to racialized narratives about what causes them to feel unsafe. In this way, they incorporate individualizing techniques of governmentality, which allows the state to free itself from the constant maintenance of its subjects (Goldstein 2010, p. 492).

One of the many ways my interlocutors perform self-governance is by perpetuating Othering narratives about safety and security developed and perpetuated through policy initiatives during the US' "War on Drugs". As Tate asserts, the primary function of these policies is to mobilize and maintain political support as a way to legitimize existing practices (cf. Tate 2015, p. 138). These practices include racial subjugation. Consciously or not, in internalizing and propagating racist notions of what categories of people pose a threat to them, my research participants legitimize the exclusions of Black people in the US as well as in the UAE. My research demonstrates that white converts to Islam and their children describe their lack of safety in ways that allude to insecurity caused by purportedly violent Others. Additionally, class and gender undergird many assumptions that associate criminality with poor Black men. For their part, Black converts to Islam illustrate fears about institutional and state-condoned interpersonal racism in the US. ${ }^{1}$

Throughout this chapter, I outline my interlocutors' arguments while contending that securitization can be effectively used to illustrate the disproportionate surveillance and profiling of Black people in the US. In the section that follows, I briefly describe the group of people at the core of this project. Then, I describe the methods I used to conduct this research. Later, over two sections, I outline both of the dominant narratives that my research participants perpetuate. Their differing fears, I argue, derive from securitization efforts that attempt to control difference and maintain the exclusion of the Other. These endeavors are often deemed legitimate by state authorities, and even some scholars, because they take place in a so-called liberal democracy. In the UAE, however, some of my Black research participants' everyday interactions with local people center the

1 To be clear, my research participants consist of more than Black and white racialized peoples. Arab and South Asian research participants often perpetuate antiBlack sentiments that frame their Black counterparts as dangerous. I will elaborate and complicate this narrative further in a later section. 
idea of belonging to the national imaginary. The official national narrative within the UAE excludes contributions to the nation state made by Ajami, Baluch, and East African cultures (AlMutawa 2016, p. 23) and more recently non-citizen migrants. My primary interlocutors, of all races, however, feel they do belong to the national imaginary because of their relationship with UAE royalty.

\section{"The Community"}

The group of people who took part in my research call themselves "The Community." Although they are diverse, racially and nationally, they are bound together by a core group of US-citizen converts to Islam. All but one of these core converts are men. They are considered central to the collectivity by other Community members and by the Sharjah ${ }^{2}$ royal family who sponsored them to migrate to the UAE in the early 1990s. Racially, they consist of two Black converts to Islam and three white converts to Islam. They all converted in the late 1970s and early 1980s, where they were introduced to Islam by friends in high school or college. A few learned about the religion while on military duty overseas, and others read about the religion on their own. Each of them describes moments where they knew they were called to Islam, usually after a dream or a feeling of comfort after the idea to accept Islam crossed their minds. Almost all of them describe seemingly serendipitous meetings with other inspiring Muslims and sometimes chances to turn their lives around. Other members of the Community and even ruling elites admire these converts for the insistence on leaving their pre-Islamic lives behind in their pursuit of zealously practicing Islam.

Many of my research participants describe an initial hesitance to convert to Islam because of fear of rejection from their family and friends, and most did experience rejection from those closest to them. Over time, the mothers of two other core Community members eventually converted to Islam, but family members converting is not common among non-born Muslim Community members. While some converts within the Community maintain contact with their families, they still describe incidences of discrimination or strain between them and their non-Muslim family

2 Sharjah is one of the seven emirates that make up the United Arab Emirates. The city of Sharjah within the eponymous emirate is the third-most populous city in the country. Cf. fig 1 . 


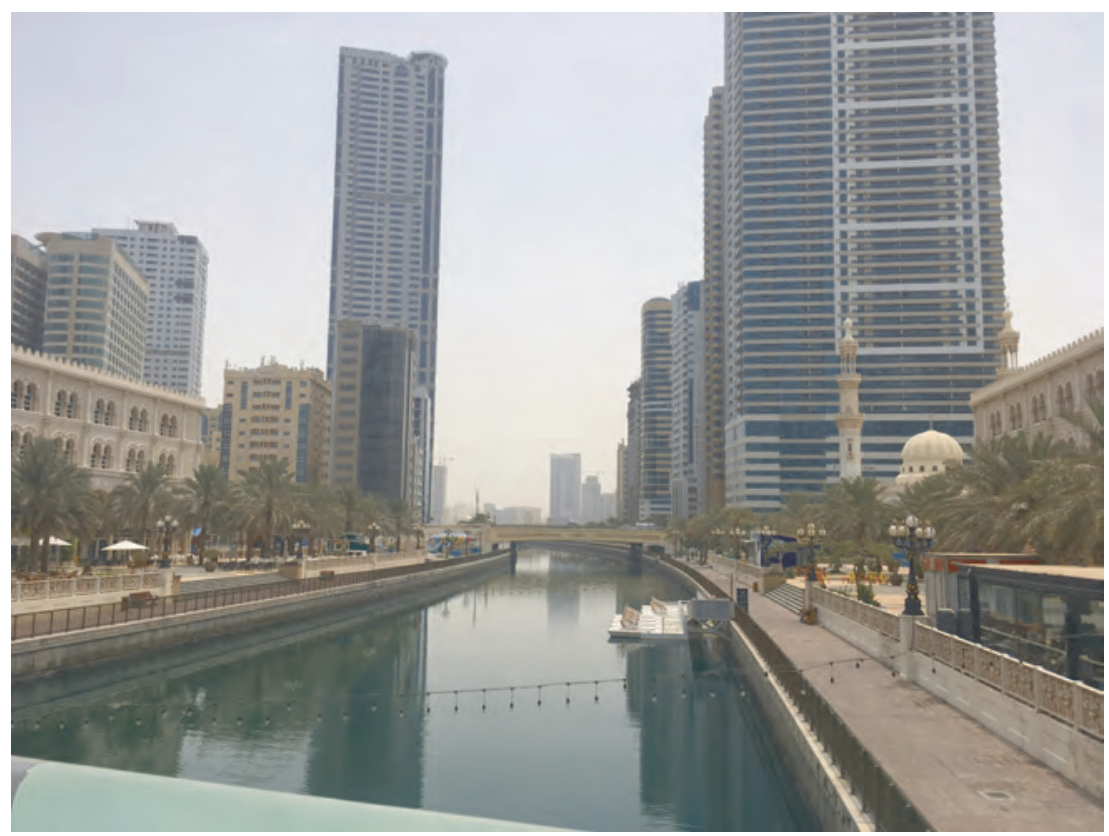

Fig. 1: Sharjah city, UEA, seen from the perspective of Qanat al Qasba on the western side of the city, 30 June 2018 (Photo: Shaundel Sanchez)

members. Children of converts more openly share that they think their extended families are insensitive about their mixed-race ${ }^{3}$ identities and about their religious affiliation. Thus, maintaining "The Community" and relationships with Sharjah royalty is imperative to those who do not have their family of origin for support.

After living in the UAE for almost a decade, they began to assist other Muslims in their migration to the country. Frequently, US-citizen Muslims who migrated through other networks became affiliated with "The Community"; however, they were rarely associated with the same sect of Islam. These people are loosely connected with "The Community", but they are still central to my research for their outsider-insider insight. In total, I

3 Most of my primary interlocutors' married people of different races or different nationalities. My white US-citizen convert research participants, for example, married nationals from South Asian or Middle Eastern countries. It is for this reason that their children will often consider themselves mixed-race, even though peoples from South Asia and the Middle East are officially considered white on US census data. 
spent time with, spoke to, and asked to do research with over 150 people who are somehow associated with "The Community". Racially, $17 \%$ of my total interlocutors are self-identified African Americans or Africans; $27 \%$ are self-identified South Asian American or Arab American, and interracially South Asian and Arab; while the remaining 56\% are self-identified white Americans or interracially mixed of Arab or South Asian descent.

Before migrating to the UAE, my core interlocutors became involved with Tablighi Jama'at (Preaching Party), an Islamist movement that originated in India in the 1920s. The members married people with different nationalities while traveling globally on religious missions with other adherents of the Islamist movement. Tablighis pride themselves on their racial, national, and socio-economic diversity. More importantly, they claim that despite their diversity, members remain tolerant of each other and are treated as equals.

Tablighis make khuruj (religious mission) globally and domestically for three days to six months at a time. Missionaries are mostly men who travel from country to country and city to city, staying in mosques or with other adherents to invite people to practice Islam, a proselytizing process called da'wa. Sometimes their wives, daughters, and nieces join them, but more often, women stay at home while men leave to make khuruj. Performing $d a^{\prime} w a$, a central part of these missions, is one of the six tenets of Tablighi Jama'at.

The amount of time that Community members spend together performing these tenets highlights their efforts towards a unified mission of serving Allah and inviting Muslims and non-Muslims to practice Islam. Doing these tasks together often masks disparities between adherents. Ruling elites from Abu Dhabi and Sharjah sponsored the core Community members, US-citizen converts to Islam, to live in the country. These ruling elites were, and some continue to be, active in Tablighi Jama'at. However, Tablighi Jama'at does not have an official position within UAE governance. In fact, many Emirati citizens and non-Emiratis with some interest in the UAE will affiliate Sharjah royalty with Salifism (a reform branch of Sunni Islam) because of stereotypes about Salafis' strictness and the perception that Sharjah royalty are religiously zealous. My experiences, although brief and respectful, with Sharjah royalty and those connected to royalty are that some practice many different forms of Islam and some do not practice the religion at all. For those royalty affiliated with Tablighi Jama'at, they choose not to publicize their official position within the UAE while partaking in khuruj as a personal principle. It is for this reason that my research participants are shocked to learn that royalty were among their closest Tablighi friends. 
The first Community member to gain sponsorship from royalty to live in the UAE was Yusuf (all names are pseudonyms), a white convert to Islam. So, he is considered its founding member. It was at his funeral, in 2010, that I first came to learn about my interlocutors, and Community members frequently tell his migration narrative. Yusuf became Muslim as a teenager after reading the Qur'an. He moved to San Francisco from the American Midwest to work in a large mosque. One day while at work, he came across some well-known Tablighi Jama'at members making khuruj. He was intrigued by their message, and they were equally fascinated by his conversion to Islam. Yusuf immediately began performing khuruj with these Tablighis, and he was successful at delivering da'wa. His piety, severity of practice, and conversion at an early age appealed not just to Muslims, but also non-Muslims interested in converting to the religion. Yusuf's reputation as a successful $d a^{\prime} i$ (person who performs $d a^{\prime} w a$ ) allowed him to gain access to and marry one of the daughters of a prominent Bangladeshi Tablighi in the 1980s. Immediately after marrying in Bangladesh, Yusuf and his wife moved to the US, where his wife gave birth to three of their five children. But in the early 1990s, because they felt unsafe living in the US, Yusuf and his family decided to move to one of the countries where he had made khuruj, Jordan. They were also driven by the desire to raise their children in a Muslim-majority country.

Yusuf and his family did not find the safety they sought when they first moved to Jordan. On the contrary, they felt unsafe there too, but for reasons different than those in the US; they lacked financial security, and Yusuf was unable to secure an intermediary to find a job for him. Like Yusuf, many of my interlocutors describe other Muslim-majority countries as unsafe because of economic instability or frequent political upheaval. The core members' notions about the UAE as economically safe derive from the financial support that they receive from royalty, including reduced rent and sometimes even jobs. This financial support protects these members from financial insecurity during the country's economic disruptions. They also imagine that their relationship with Sharjah royalty provides them with safety not provided to most others in the country.

After living in Jordan for a brief period, Yusuf made Hajj (religious pilgrimage to Mecca) with other Tablighis, and while there, he met up with some other adherents. During his trip to Mecca, Yusuf learned that one of his friends was a sheikh (male royal family member) in the UAE. Like my other research participants, Yusuf had no conception of Arab royalty. The royal family member explained to him that he had a unique role and position in the UAE. Then, he invited Yusuf and his family to move to the UAE, where, he explained, they would find safety and a Muslim-majority 
environment, and their royal connection - the sheikh himself - would ensure that they had financial support or access to jobs.

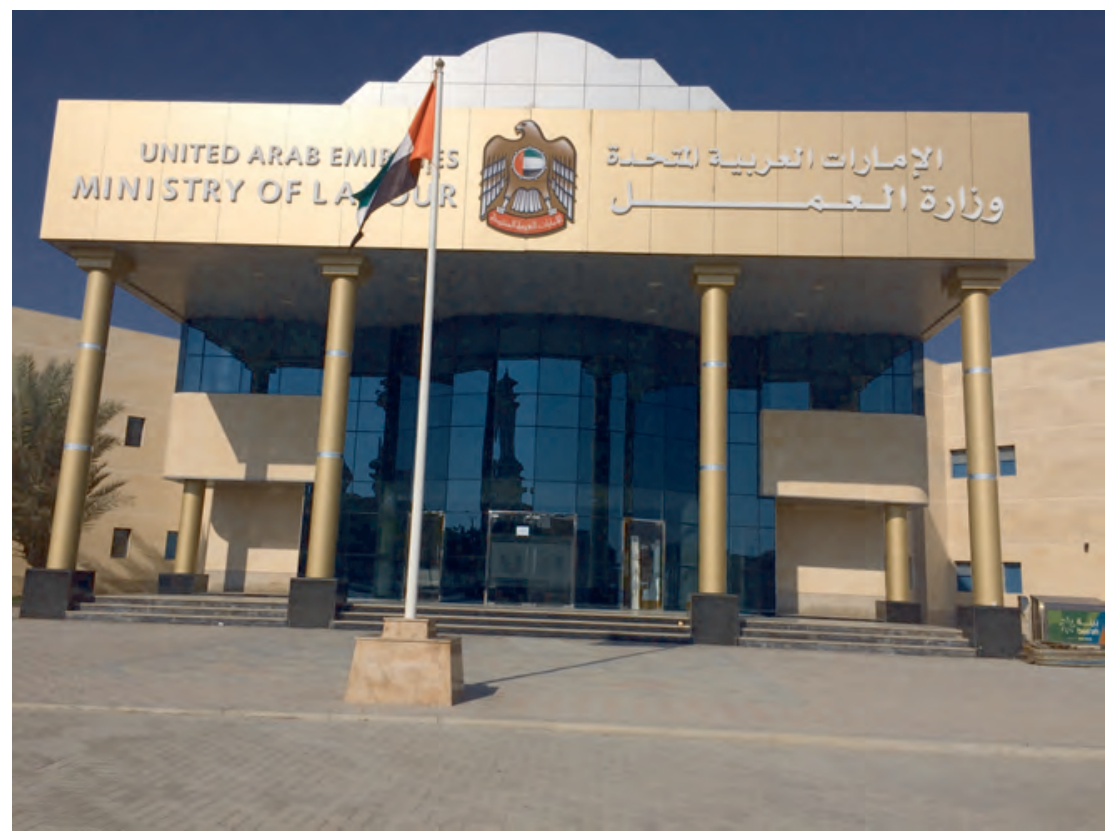

Fig. 2: Ministry of Labour Office, Sharjah city, UEA, 2 January 2016 (Photo: Shaundel Sanchez)

In order to migrate to the UAE, non-Emiratis must obtain sponsorship via the official kafala (sponsorship) system ${ }^{4}$, but few such individuals have as many privileges as Yusuf and my interlocutors who receive royal sponsorship. Scholarship on migrants living in the Gulf focuses on the many ways the kafala system is exploitative, especially for low-wage laborers from the Asian subcontinent (cf. Babar/ Gardner 2016; Gardner 2010; Khalaf 2014; Longva 1997). One of the central problems of the kafala system that these researchers highlight is that it permits and encourages exploitation of migrant workers by confiscating migrants' passports, perpetuating a system dependent on debt collection in order to enter the country, withholding

4 The Ministry of Labour office in Sharjah governs all work-related issues in the emirate, which is especially important for foreigners who have entered the country under the kafala system. Cf. fig. 2. 
or limiting payments, allowing sponsors to deport migrants, and holding migrant laborers beyond their two-year contracts against their will (cf. Babar/Gardner 2016).

For Babar and Gardner (2016, p. 50), macro-level migration policy in the Gulf states, including the UAE, aims to decrease dependency on foreign laborers. By reducing the number of foreign laborers who enter, states that use the kafala system ${ }^{5}$ can improve citizens' representation in the local workforce and reduce the threat of cultural or socio-political displacement (Babar/Gardner 2016, p. 50). Lori describes similar goals posed by the ruling elites in the UAE who continue using the kafala system in coordination with other techno-security measures that function to protect national security (Lori 2011, 2012 and 2019). In this case, national security includes protecting the nation from the alleged criminal and cultural impacts of migrants (Lori 2011). In this literature, scholars assert that state governing authorities label foreign laborers a cultural and criminal security threat. Therefore, non-Emiratis are excluded from national belonging.

Some scholars of the Gulf have begun to elaborate on the ways noncitizens do feel they belong in the UAE (cf. Koch 2016a; Vora 2013; Vora/ Koch 2015). My research participants similarly feel that they belong in the UAE and contribute to its national imaginary. This chapter more closely focuses on their complicated, conflicting, and security-driven reasons for emigrating from the United States. For this reason, to understand their motivations, I highlight what they told me in formal and informal narratives during several regularly occurring activities from 2015 to 2019.

\section{Methods}

I conducted the bulk of my research in Sharjah, UAE, where most of my interlocutors live. In 2003, one Sharjah royal family member built a neighborhood for "The Community" on the outskirts of Sharjah city. Informally called "The American Neighborhood," its name emphasizes the importance of the US-citizen converts to Islam as core Community members. I also followed my research participants as they re-migrated to the US, which some started doing in 2010, with many more following in 2015. Although they did not necessarily want to return to the US, several factors compelled them to, including: US overseas tax law known as the

5 The following eight countries use the kafala system: Bahrain, Jordan, Kuwait, Lebanon, Oman, Qatar, Saudi Arabia, United Arab Emirates. 
Foreign Account Tax Compliance Act (FATCA), fathers' inability to sponsor their sons after the age of 18 under the kafala system, and the desire for their children to obtain an affordable secondary education (cf. Sanchez 2019). For these reasons, I began following my research participants to Massachusetts and Missouri in 2017, where they had established networks to ease their re-migration.

To learn their reasons for emigrating from the US in the first place, I primarily conducted migration narratives. Inspired by Quinn, who establishes that narratives are one particular point in collaborators' life stories (Quinn 2005, p. 27), I began interviews by asking my interlocutors to discuss their migration narratives. I audio-recorded 22 of these narratives, while collecting and compiling in my field notes hundreds of "conversational narratives" (Hill 2005, p. 158) from over 150 research participants. For Hill, conversational narratives are "oral narratives that emerge as interactional moves within larger conversations" (ibid.). The ideas that developed from these everyday conversations covered the same themes as formal narratives but happened in my day-to-day interactions with Community members.

In addition to conducting formal and informal narrative interviews, I participated in formal and informal focus groups during dinners, halaqa (Islamic learning circles) (cf. Ahmad 2017), and tea and coffee gatherings. Each of these activities occurred once or twice a week and lasted between one and seven hours. Community members, as these activities indicate, spend a lot of time together, and their constant meetings and activities strengthen their group cohesion. As discussed below, however, their presentation as a unified group is not without hidden tensions.

When possible, my interlocutors also maintain strict gender segregation. In the United States, women and men are unable to stay in separate spheres because their homes are smaller than they are in the UAE. The UAE also provides areas outside the home that are more conducive to gender segregation. Yet, they segregate along gender lines in both the US and UAE when conducting the activities outlined above. Because of my identity as a Muslim woman, Community members expected me to do the same. Therefore, I mostly took part in what Abu-Lughod calls "women's worlds" (Abu-Lughod 1988, 1990 and 1993). However, if a female research assistant from The Community were present, men agreed to formal interviews, whether recorded or not. Over time, men began speaking to me in public settings more frequently as our paths crossed, especially in the US.

The narratives that I collected, formally during interviews and informally during the activities mentioned above, revealed the fissures within "The Community". Resting along complicated intersectional (but more explicit- 
ly racial) lines, Community members have only obliquely described these fissures. The following sections illustrate my interlocutors' reasons for migrating to the UAE.

\section{Racialized Narratives of Fear}

I use many definitions of "fear" when describing why my interlocutors (or their parents) left the US in the early 1990s. The first definition is political fear, which Robin $(2004$, p. 2) outlines as "a people's felt apprehension of some harm to their collective well-being - the fear of terrorism, panic over crime, anxiety about moral decay - or the intimidation wielded over men and women by governments or groups". The second definition, from Ahmed (2004, p. 65), includes notions of proximity, where fear is a response to something approaching. When the fearsome object passes by, however, the threat does not simply disappear. Instead, it is suspended. Ahmed describes an emotionality of fear that is not tethered to notions of rationality. Schwell (2015) adds to Ahmed's definition that fears are simultaneously collective and individual, social and personal, deeply moral, and highly political. Fear, as presented in these definitions, is central to any analysis of securitization. Governing technologies, and those whom they govern, (re)produce, (re)enforce, and implement security measures based on political and emotional fears.

Fear is something often taken for granted in security scholarship, which has promoted the "culture of fear" literature in which the audiences' conduct and emotions have been guided by this so-called culture (Schwell 2015, p. 99). In this understanding, fear becomes pervasive, all-encompassing, and very often, an unavoidable technology of governance (cf. Ahmed 2004; Schwell 2015), aligning with its political definition. However, as Schwell argues, and as I have determined, audiences are not passive actors in securitization efforts. Instead of accepting that citizen or non-citizen subjects may willingly consent to and perpetuate fears based on governing authorities' speech acts or technologies, I assert that my interlocutors act as securitizing agents by reproducing narratives that maintain profiling of the perceived dangerous Other.

The first set of narratives I present comes from my white self-identifying interlocutors, as well as some South Asian and Arab research participants. One example of their anti-Black sentiment comes from a recorded interview with my research assistant, Zainab. Zainab's mother is a white convert to Islam, and her father was born in Libya but lived most of his life outside of his home country. During our interview, she insisted 
that her parents wanted to emigrate from the US because of rising gang violence in Colorado, sharing an anecdote about how gang violence led to a child dying from a gunshot wound in her family's backyard. This sentiment was not uncommon in the everyday narratives that many Community members shared. Other research participants discussed frequent kidnappings as a reason they and their families fled the US. One Arab American Community member, Sarah, told me that her parents wanted to move to the UAE because her parents wouldn't have to worry about "just blinking an eye and their kid just wasn't there anymore."

Potential gang violence and child kidnappings are two common reasons for moral panic that Beckett (1997) and Glassner (2010) identify, "moral panic" referring to unfounded forms of widespread violence that draw attention away from more imminent structural dangers. In the early 1990s, some of the structural dangers that afflicted US populations included mounting poverty, a widening wealth gap, lack of access to health care, and an ever-growing prison population. Davis and Mendieta argue that moral panic erupted at a conjecture that, in reality, was not about a rise in crime, but rather, focused on managing large Populations of Color. These Populations of Color, they contend, had been rendered disposable by the system of global capitalism (Davis/Mendieta 2005, p. 41).

Zainab's and Sarah's examples do not mention the race, gender, or class of the gang members or the child kidnappers whom their parents feared. However, one of my Arab American interlocutors, Sheyla, shared a similar reason for wanting to emigrate from the US, and she was more explicit. Her anecdotes about abuse explicitly name Black men as violent criminals, as a dangerous Other. In one such narrative, which she told me in 2015, a Black man waved a gun as he entered her US home. At the time, she was married and had two young children. It was fear for her children's safety that upset her most about the incident.

The next year, in 2016, another incident with Sheyla betrayed her conflation of race and criminality. Following a dinner at a Community member's home, Sheyla walked me to the house in Sharjah where I was staying. Although the distance between the villas was a mere 30 steps, Sheyla insisted on escorting me. Halfway to the house, she asked if I was nervous about walking alone. I replied, "No, the walk is less than 30 steps, and we know everybody in this neighborhood." To which, her response was, "Well, in America, $\mathrm{n}^{* * * * * *}$ s would come and get you." I was initially shocked, and until that point, Sheyla had been more covert about her antiBlack sentiment. After this incident, I began inquiring about Sheyla's and others' perceptions of criminality and race, and I started to understand the fissures within the Community as expressed in their migration narratives. 
Not all my research participants are ignorant to racial differences. Yasmine is a 20-year-old American woman of Arab, Bangladeshi, and Latin American descent, and she, like her family members, often boasts these three facets of her ethnic identity. Her primary residence is in Missouri with her nuclear family, but she spends between three to six months each year in Sharjah, staying with her grandparents and extended family. In July 2018, we went to a water park in Sharjah together. While wading in the lazy river, we discussed her feelings of safety in both the US and the UAE. She said that she feels safer in the UAE because of the "problems people of all races face with people of other races" in the US. She continued by adding that "Blacks have to worry about whites and whites worry about lots of other poor people from other races."

In fact, this conversation about race was a continuation of one Yasmine and I had begun months prior, when I traveled to Missouri for fieldwork in the winter of 2017-2018. Most of our discussions were about the protests that developed after the murder of Anthony Lamar Smith by police officer Jason Stockley in St. Louis, near Yasmine and her family's suburban home. She also shared her opinions about the protests in nearby Ferguson, after Michael Brown was shot and killed by police officer Darren Wilson. She was not sympathetic towards the protesters and even insisted that it is un-Islamic to support protests. Her position against protesting likely derives from her connection to Tablighi Jama'at. Tablighis shun scrutiny of governments to ensure they can travel freely between nation-states to perform their religious missions (cf. Sikand 2002).

Yasmine is not white-passing, although her siblings and her parents are, minus the face coverings and long cloaks (abayat) worn by the women in her family. They are also upper-middle class, although this has not always been the case. So, for me, the connection she made between racial tensions and fear was not surprising. Her simplistic divides about white people fearing people of all other races, and Blacks fearing only whites, demonstrates a larger narrative regarding securitization in the US. The sometimes explicit, more often implicit narrative that I heard from non-Black Community members focused on the conflation of Black men and criminality. Yasmine more specifically said that protesting in support of Black Lives Matter or against police brutality was against basic principles in Islam; therefore, it was impermissible for Muslims. This statement also negates the large Black Muslim population in the US who have mostly been supportive of and central to the Black Lives Matter movement.

These narratives highlight the use of fear that legitimizes securitization efforts in the US, securitization efforts that align with Davis and Mendieta's argument, cited above, that the goal of security measures is to manage 
Populations of Color as opposed to deterring violence in any real sense (Davis/Mendieta 2005, p. 41). Mofette and Vadasaria address this process by introducing a framework of racial governmentality, which "helps to explain the overt and insidious ways that nonwhite populations, and notably their bodies, are read and treated as threatening and violent" (Mofette/Vadasaria 2016, p. 295). This form of governmentality relies on notions of racial difference that allow for debasing practices, including racial profiling, imprisonment, deportation, police brutality, and targeted killings (cf. ibid). These forms of racial governmentality in the US are rendered visible in the overwhelming African American and Latinx populations in prison, as well as in various policies that overtly or covertly focus on criminalizing Black people including, but not limited to, New York State's Rockefeller Drug Laws, the federal Anti-Drug Abuse Act of 1988, and the federal 1994 Violent Crime Control and Law Enforcement Act.

However, this is not to diminish the fact that racial governmentality is also mobilized through "internalized racial logics and rationalities, selfsurveillance and regulation" (Mofette/Vadasaria 2016, p. 295). My white research participants, and sometimes my South Asian and Arab interlocutors, perform these racial logics and rationalities by perpetuating the image of Black people and some Latinx populations as criminals, kidnappers, or merely, as the 'dangerous Other'.

\section{Fearing Securitization}

Alternatively, Black collaborators assert that they felt unsafe because of institutional racism, which disproportionately profiled them. One such example comes from Zahid, a Black convert to Islam. When I first interviewed him in June 2016, he told me that he decided to emigrate in the late 1980s because he was addicted to cocaine, saying, "Our generation at that time, Black professionals in America, it was an epidemic amongst us, doctors, lawyers, politicians. It's almost like we were targeted. It's not an excuse. It's just the reality." He added that it was his mother who finally told him to migrate to one of the countries where he traveled to make da'wa on khuruj, fearing that if he remained in the US, he would either die or be imprisoned for his drug habit.

During the above portion of his interview, Zahid references the Reagan administration's "War on Drugs" as a reason he feared imprisonment and death. Based on the perception that lower-income Black and Latinx communities used crack cocaine at higher rates, the Anti-Drug Abuse Act of 1986, a "War-on-Drugs" policy, targeted these two communities by manda- 
ting harsher penalties for the use of crack cocaine versus powder cocaine. Zahid appears to have been a powder cocaine user, which implies that, based on the law, he would not be disproportionality targeted. Yet he, like his mother, perceived that drug policies negatively affect all Black people, regardless of the type or texture of drug used.

In the 1980s, when Zahid was most heavily into drugs, cocaine use had steadily increased in the US. According to Mamdani (2004, p. 349-350), between 1982 and 1985 , cocaine use rose by $38 \%$ to 5.8 million users. The moral panic about cocaine use contributed to increasing the Black prison population for drug-related offenses, even though, statistically, most cocaine users are white (cf. Sudbury 2008, p. 346-347). The "War on Drugs" and mandatory minimum prison sentences for drug offenders tripled the incarceration rate of African American men (cf. Lane et al. 2004). These securitizing efforts are supported by moral-panic narratives about rampant drug use that legitimize disproportionally punishing Black and Latinx people in the US.

Abu Sultan, a Black convert to Islam who is central to "The Community", described the hatred he felt for white Americans because of the trauma he experienced in the US. In an interview on June 2016, he told me that "there was a time when I hated white Americans. My mother took me aside and said, 'I never knew somebody filled with so much hate in my whole life!' Because I had become traumatized. I had become traumatized by what was happening in the '50s and " $60 \mathrm{~s}$. I had it in my mind that I would never do these things, and it would never happen to me." In this segment of his interview, Abu Sultan references the Civil Rights Movement, wherein leaders and everyday activists were profiled, put on FBI watchlists, or murdered for their affiliation with the movement.

As he continued, he shared with me that what changed his mind was going to Jordan during his time in the military as a young adult. Describing Jordanians as white, he told me that his time in Jordan made him realize that he did not have hate for white people, but that he did not like oppressors. He continued, "It was these people that were oppressing my people. They made it a black and white thing. They did that!" He describes "they" as an unidentified "group of people" in the US.

In Zahid's and Abu Sultan's experiences, they describe how often they felt uncomfortable, stereotyped, and unable to live freely because of institutional racism. Zahid specifically feared punitive actions, while Abu Sultan felt enraged by the remnants of white supremacy. These two men are integral to the cohesion of "The Community". They assisted Muslim converts and others with the Community in their migrations to the UAE throughout the 1990s and the early 2000s. Interestingly, they also express 
notions of safety and fear that influenced their choice to emigrate from the US. However, they describe fear of racialized securitization mechanisms during specific moments in the United States: The Civil Rights Movement and the peak of the "War on Drugs". In examining these two narratives from one group of US-citizen expatriates living in (or who have lived in) the UAE, one can observe what Moffette and Vadasaria (2016, S. 294) call "the qualitative shift that securitizing moves introduce in the everyday governance of racialized individuals and migrants." This qualitative shift permits researchers to understand the everyday ways securitization affects people and their roles in perpetuating securitization.

\section{From Fear in the United States to Belonging in the United Arab Emirates}

I've presented two broader narratives that illustrate the (mis)handling of difference in securitization efforts between citizen-subjects. The Community members in my research describe their fear as a feeling influenced by politically-laden securitization. However, they do not acknowledge, or may not be conscious of, the political motivations behind their different notions of safety. Their narratives hinge on their interpretations of whom and what to fear.

Both perceptions, importantly, demonstrate that racialized groups have been securitized by governing authorities' speech acts and "through everyday practices of classification, categorization, and policing" (Moffette/Vadasaria 2016, p. 293). In these ways, it becomes apparent that "race is also central to the logic of the surveillance state," which determines who does and does not belong (Abdul Khabeer 2016, p. 200). I have also illustrated that citizens (re)produce state violence and exclude racialized groups through othering narratives of safety and fear. My white, South Asian, and Arab American interlocutors' narratives illustrate Wilderson's assertion that "blackness is always-already criminalized in the collective consciousness" (Wilderson 2018, p. 47).

Perpetuating racialized narratives of fear undoubtedly legitimizes the state's extraordinary and everyday security measures, which include racial profiling and mass incarceration of Black and some Latinx peoples. Scholars opposed to critiquing securitization theory have overwhelmingly quashed efforts to draw attention to the everyday effects of these Othering narratives and techniques. When scholars choose to avoid race in discussions about securitization for fear of seeming too focused on "identity politics," they reinforce what Dyson asserts are "false racial equivalences between white fear and black suffering" (Dyson 2016, p. 407). White fear, 
Dyson establishes, is driven by the disgust of sharing social space with Black people rather than any fear of Black crime. Wilderson also adds that the true locus of Black Americans' problems in the US derives from the reality that captivity and coercion was the initial point of Black Americans' interaction with the state and with white citizens (Wilderson 2018, p. 46). He argues that violence against Black Americans is one tactic of a larger strategy to secure humanity's place (ibid, p. 48). It is in this way that anti-Blackness as a theoretical framework "describes the inability to recognize black humanity" (Ross 2020, p. 2) and places Black Americans outside of those who benefit from securitization. Instead, Black people are depicted as those who require securitizing.

Despite being members of a close-knit community, my interlocutors describe narratives of fear that implicate some Community members as the dangerous Other. Community members have reconfigured their antiBlack narrative into another narrative about national belonging in the UAE. For example, during a June 2017 interview with Nilou, a 21-year-old Pakistani member of "The Community", she explained that real Emiratis would never marry non-Emiratis. Nilou lived in Satwa, which is an area that primarily houses Emiratis located in Dubai. For her, living among Emiratis allowed her to learn who is not a real Emirati. I realized after this interview that some of my interlocutors, when they discussed real versus not real Emiratis, were indirectly speaking about other women within "The Community" who married Emirati men.

Nicole, one of the Community's white US-citizen converts to Islam, shared with me that other Community members often tell her that her husband is not a real Emirati because he is Black. After talking with Nicole and other Community members about the racial and national identities of their spouses, it became clear to me that belonging is central to Black Emiratis' experiences in the country. Notions of belonging within Emirati society are also informed by race and the historic slave trade from East Africa and the Indian Ocean world. Most Emiratis with African lineage can trace their lineage to the late nineteenth and early twentieth centuries, when labor demands were satisfied through the African slave trade (cf. Hopper 2014, p. 328-330). Today, AlMutawa (2016, p. 23) asserts that East African cultures and peoples are integral to Emirati culture, although they are not always represented and treated as such. It is for this reason that Emiratis with East African lineage have no incentive to disclose their heritage (Hopper 2014, p. 328). Gulf governing authorities have also downplayed the history of slavery in their states (ibid, p. 344). Hopper adds that not all Africans in the Gulf have been slaves and not all slaves were African, but there was limited voluntary migration from Africa 
(ibid, p. 328). As discussed above, preferential migrant populations have fluctuated in the UAE based on perceptions of acceptable and desirable characteristics of foreign laborers. Desirable laborers are those who do not pose a purported criminal and cultural threat to the UAE.

In light of this history, Black "Community" members shared incidents when they were questioned about their nationality in ways that erase their connection to their own nation-state, as is the case for Black Emiratis within the UAE. Asya is a Black American convert to Islam who migrated to the UAE in the early 2000s. During an interview in January 2016, she shared with me several incidents in which Emiratis asked her if she is "American, American", meaning American by birth and not by naturalization. She continued to describe how many Emiratis and other Arabs think she is American in "passport only," and not born in the US because she is Black and Muslim.

How one obtains one's US citizenship - by birth or through naturalization - for Emiratis reflects the distinction between the different citizenship statuses with their corresponding documentation in the UAE. There are three distinctions of belonging associated with various forms of legal citizenship or residency. The first form of belonging is when one is considered an ethnic Emirati, if they have a family book and can trace their lineage to some of the original families from the area. This is the type of ethnic citizenship that allows one to vote and benefit from all social services in the country. Then there are those who have become naturalized later, usually through women via marriage. This law has recently changed to allow Emirati women to pass down their citizenship to children of non-Emirati men, but often children describe their national and ethnic affiliation based on their father's ethnic identity. Finally, there are those who have lived in the region since before official nationhood, yet do not possess a family book or a passport. Black Emiratis, according to my research participants, are suspect to Emiratis and many non-citizen residents in the country when claiming to pose citizenship through their family book. This derives from the ignorance that Black Emiratis, and other Baluchi and Ajami Emiratis, experience in the UAE. Clearly, notions of belonging in specific geographical locations and Blackness are not new to the UAE. This specific history also affects my research participants, in addition to the racialized security efforts in the US. 


\section{Conclusion}

In this text, I have demonstrated that my interlocutors adopt two separate narratives about safety that have informed their decision to emigrate from the US. These narratives derive from notions of the dangerous Other informed by the history of the US' structural organization around race as one of many categories of differentiation - race being, arguably, the most central category of differentiation throughout US history. The US emerged as a slave society built on the backs of Africans and their descendants. Then, governing authorities implemented and enforced legal segregation, which produced a country with a deeply entrenched structural inequality in which race is one of the central components (Bhambra 2017, p. 225). These forms of inequality and structural racism are visible in securitization in the US, where the implicit and explicit dangerous Others are Black and other People of Color. Policies created to complement the "War on Drugs" or targeted killings and activist suppression during the Civil Rights Movement demonstrate that racism is central to security efforts in the US.

These metanarratives are informed by calls to securitization that claim to protect abstract concepts of freedom and democracy. They function by obscuring racial profiling in surveillance and incarceration. My interlocutors may not succumb to regional metanarratives that depict the US (and the so-called West) as safe compared to the region referred to as the Middle East, but they perpetuate notions of safety about certain bodies nonetheless. It is not to any Community member's benefit to give credence to racist narratives about dangerous Others that lead to profiling - even white Muslims like John Walker Lindh, known as the "American Taliban", have been imprisoned for their connection to known terrorist networks - but they do maintain narratives about the dangerous Other all the same. Perpetuating prejudices that depict African Americans as the dangerous Other within their emigration narratives is an individualized form of governmentality. These narratives demonstrate the ways the state has relinquished its role of governance to everyday citizens. Remaining vigilant, as the "See Something, Say Something" campaign' suggests, has encouraged everyday citizens to take up the role of security in their own

6 The New York Metropolitan Transportation Authority originally trademarked the "See Something, Say Something" campaign in 2002. The Department of National Security licensed the slogan and began a national campaign in 2010. The program aimed to raise public awareness about indicators of terrorism with the emphasis of reporting suspicious activity. Thus, it relied on vigilant everyday citizens to report what they believed was suspicious activity. 
hands. My white interlocutors' narratives about fearing criminality and associating such criminality with African Americans demonstrates the ways they individually configure security.

Race and the African diaspora do not necessarily have the same trajectory, forms of identification, and contemporary issues with structural violence in the UAE as they do in the US. For one, Black Americans and American People of Color are consistently profiled and imprisoned at a rate that far exceeds that of white Americans. The fear they have about being profiled, imprisoned, or worse, murdered by public servants is central to their experiences with American liberal democracy.

For Emiratis with African lineage (slave or otherwise) in the UAE, their history has been conveniently forgotten to promote an official national narrative that erases the centrality of Ajami, Baluch, and East African cultures (cf. Al Mutawa 2016, p. 23). My interlocutors have also adopted these perceptions about race and belonging in the UAE. They perpetuate ideas that Emiratis with African descent do not belong in the national imaginary of the UAE. This notion solidified in the UAE due to the need for a single national narrative. My interlocutors, however, easily perpetuate anti-Black sentiment when living in the UAE because of their experiences with US racial securitization. In the UAE, notions of who does and does not belong propagate the country's contemporary securitization and technological efforts to depict some non-citizen foreign Others as a criminal and cultural threat. The careful distinctions between types of citizenship and non-citizenship illustrate some of the erasure and sometimes formal exclusion experienced by those without a family book, or ethnic citizenship. Because my interlocutors have established relationships with UAE royalty who provide them with benefits and a sense of safety, they often experience life in the UAE as if they are outside these securitizing mechanisms that preserve stereotypes of foreigners as criminal and cultural threats.

In the case of "The Community", securitization, as anthropologists have theorized it, permits one to understand the fissures inherent in narratives about fear. These fissures lie along racial lines but are not explicitly discussed between members. The differing narratives demonstrate the everyday pervasiveness of racial governmentality and violence experienced by Black communities, in particular in the US, as a symptom of securitization (cf. Moffette/Vadasaria 2016, p. 291). Community members' different interpretations of safety, dangerous Others, and institutional racism demonstrate the centrality of race in US securitization. However, their narratives of emigrating from the US to escape their fears by migrating to the UAE illus- 
trate the need to move beyond metanarratives (cf. Koch 2019), including those that deem certain regions "safe" and others "unsafe".

\section{Works cited}

Abdul Khabeer, Su'ad (2016): Muslim Cool: Race, Religion, and Hip Hop in the United States. New York, NY: NYU Press.

Abu-Lughod, Lila (1988): Fieldwork of a Dutiful Daughter. In: Altorki, Soraya/ El-Solh, Camillia Fawzi (eds.): Arab Women in the Field: Studying Your Own Society, Syracuse, NY: Syracuse University Press, pp. 139-161.

Abu-Lughod, Lila (1990): Can There Be a Feminist Ethnography?.In: Women and Performance: a Journal of Feminist Theory 5 (1), pp.. 7-27.

Abu-Lughod, Lila (1993): Writing Women's Worlds: Bedouin Stories. Los Angeles, CA: University of California Press.

Ahmad, Attiya (2017): Are They Married?: Muslims Marriages and the Interrelationship between Transnationalism and Ethnonationalism in the Gulf. In: Journal of Middle East Women's Studies 13 (1), pp. 3-24.

Ahmed, Sara (2004): The Cultural Politics of Emotion. Edinburgh: Edinburgh University Press Ltd.

AlMutawa, Rana (2016): Monolithic Representations and Orientalist Credence in the UAE. In: Gulf Affairs: Oxford Gulf and Arabian Peninsula Studies, pp. 2225.

Babar, Zahra/Gardner, Andrew (2016): Circular Migration and the Gulf States. In: Solé, Carlota/ Parella, Sonia/Sordé Martí, Teresa/Nita, Sonja (eds.): Impact of Circular Migration on Human, Political and Civil Rights, Switzerland: Springer International Publishing, pp. 45-62.

Beckett, Katherine (1997): Making Crime Pay: Law and Order in Contemporary American Politics. New York: Oxford University Press.

Bhambra, Gurminder K. (2017): Brexit, Trump, and 'Methodological Whiteness': On the Misrecognition of Race and Class. In: The British Journal of Sociology 68 (S1), pp. 214-232.

Buzan, Barry/Wæver, Ole/de Wilde, Japp (1988): Security: A New Framework for Analysis. Boulder: Lynne Rienner Publishers.

Davis, Angela Y./Mendieta, Eduardo (2005): Abolition Democracy: Beyond Empire, Prisons, and Torture. New York: Seven Stories Press. EPUB.

Diphoorn, Tessa/Grassiani, Erella (2015): Introduction: Security. In: Etnofoor 27 (2), pp. 7-13.

Dyson, Michael Eric (2016): The Black Presidency: Barack Obama and the Politics of Race in America. New York: Houghton Mifflin Harcourt. EPUB.

Gardner, Andrew (2010): City of Strangers: Gulf Migration and the Indian Community in Bahrain. Ithaca: Cornell University Press. 
Glassner, Barry (2010): The Culture of Fear: Why Americans Are Afraid of the Wrong Things, Tenth Edition. New York City, NY: Basic Books.

Goldstein, Daniel M. (2010): Toward a Critical Anthropology of Security. In: Current Anthropology 51 (4), pp. 487-517.

Hopper, Matthew S. (2015): Slaves of One Master: Globalization and Slavery in Arabia in the Age of Empire. New Have: Yale University Press.

Hill, Jane H. (2005): Finding Culture in Narrative. In: Quinn, Naomi (eds.): Finding Culture in Talk: A Collection of Methods, New York City, NY: Palgrave Macmillan, pp. 157-202.

Howell, Alison/Richter-Montpetit, Melanie (2020): Is Securitization Theory Racist? Civilizationism, Methodological Whiteness, and Antiblack Thought in the Copenhagen School. In: Security Dialogue 51 (1), pp. 3-22.

Khalaf, Abdulhadi (2014): The Politics of Migration. In: Khalaf, Abdulhadi/AlShehabi, Omar/Haneih, Adam (eds.): Transit States: Labour, Migration and Citizenship in the Gulf, London: Pluto Press, pp. 39-56.

Koch, Natalie (2016a): Is Nationalism Just for Nationals? Civic Nationalism for Noncitizens and Celebrating National Day in Qatar and the UAE. In: Political Geography 54, pp. 43-53.

Koch, Natalie (2016b): Is a "Critical" Area Studies Possible? In: Environment and Planning D: Society and Space 34 (5), pp. 807-814.

Koch, Natalie (2019): Deep Listening: Practicing Intellectual Humility in Geographic Fieldwork. In: Geographical Review 110 (1-2), pp. 52-64.

Lane, Sandra D./Keefe, Robert H./Rubinstein, Robert A./Levandowski, Brooke A./Freedmann, Michael/ Rosenthal, Alan/Cibula, Donald A./Czerwinski, Maria (2004): Marriage Promotion and Missing Men: African American Women in a Demographic Double Bind. In: Medical Anthropology Quarterly 18 (4), pp. 405-428.

Longva, Anh Nga (1997): Walls Built on Sand: Migration, Exclusion, and Society in Kuwait. Boulder: Westview Press.

Lori, Noora (2011): National Security and the Management of Migrant Labor: A Case Study of the United Arab Emirates. In: Asian and Pacific Migration Journal 20 (3-4), pp. 315-337.

Lori, Noora (2012): Temporary Workers or Permanent Migrants? The Kafala System and Contestations over Residency in the Arab Gulf States. In: The Institut français des relations internationales (Ifri), pp. 1-35.

Lori, Noora (2019): Offshore Citizens: Permanent Temporary Status in the Gulf. New York City: Cambridge University Press.

Mamdani, Mahmood (2004): Good Muslim, Bad Muslim: America, the Cold War, and the Roots of Terror. New York City: Pantheon Books.

Mann, Michael (2005): The Dark Side of Democracy: Explaining Ethnic Cleansing. New York: Cambridge University Press.

Moffette, David/Vadasaria, Sharia (2016): Uninhibited Violence: Race and the Securitization of Immigration. In: Critical Studies in Security 4 (3), pp. 291-305. 
Quinn, Naomi (2005): Introduction. In: Quinn, Naomi (ed.): Finding Culture in Talk: A Collection of Methods, New York City, NY: Palgrave Macmillan, pp. $1-34$.

Robin, Corey (2004): Fear: The History of a Political Idea. New York: Oxford University Press.

ross, kihana miraya (2020): Call it What it is: Anti-Blackness. In: The New York Times. 4 June. https://www.nytimes.com/2020/06/04/opinion/george-floyd-anti -blackness.html, 06.06.2021.

Sanchez, Shaundel (2019): Protecting the Passport: Defending US Borders Built in the United Arab Emirates. In: American Anthropologist 121 (1), pp. 89-100.

Schwell, Alexandra (2015): The Security-Fear Nexus: Some Theoretical and Methodological Explorations into a Missing Link. In: Etnofoor 27 (2), pp. 95-112.

Sikand, Yoginder (2002): The Origins and Development of the Tablighi-Jama'at (1920-2000): A Cross-Country Comparative Study. New Delhi, India: Orient Longman.

Sudbury, Julia (2008): Rethinking Global Justice: Black Women Resist the Transnational Prison-Industrial Complex. In: Souls 10 (4), pp. 344-360.

Tate, Winifred (2015): Drugs, Thugs, and Diplomats: US Policymaking in Columbia. Stanford, CA: Stanford University Press.

Vora, Neha (2013): Impossible Citizens: Dubai's Indian Diaspora. Durham, NC: Duke University Press.

Vora, Neha/ Koch, Natalie (2015): Everyday Inclusions: Rethinking Ethnocracy, Kafala, and Belonging in the Arabian Peninsula. In: Studies in Ethnicity and Nationalism 15 (3), pp. 540-552.

Wæver, Ole/Buzan, Barry (2020): Racism and Responsibility - The Critical Limits of Deepfake Methodology in Security Studies: A Reply to Howell and RichterMontpetit. In: Security Dialogue 51 (4), pp. 386-394.

Wilderson, Frank B. III (2018): 'We're Trying to Destroy the World': Anti-Blackness and Police Violence After Ferguson. In: Gržinić, Marina /Stojnić, Aneta (eds.): Shifting Corporealities in Contemporary Performance: Danger, Im/mobility and Politics, New York City, NY: Palgrave Macmillan, pp. 45-59. 